\title{
ORGANOCHLORINE PESTICIDES IN PIRACICABA RIVER BASIN (SÃO PAULO/BRAZIL): A SURVEY OF SEDIMENT, BIVALVE AND FISH
}

\author{
Daniela Mariano Lopes da Silva*\#, Plínio Barbosa de Camargo e Luiz Antonio Martinelli \\ Centro de Energia Nuclear na Agricultura, Universidade de São Paulo, Av. Centenário, 303, 13416-000 Piracicaba - SP, Brazil \\ Fernando Mauro Lanças e Jair S. S. Pinto \\ Instituto de Química de São Carlos, Universidade de São Paulo, São Carlos - SP, Brazil \\ Wagner E. Paiva Avelar \\ Faculdade de Filosofia Ciências e Letras de Ribeirão Preto, Universidade de São Paulo, Av. dos Bandeirantes, 3000, \\ Ribeirão Preto - SP, Brazil
}

Recebido em 10/10/06; aceito em 19/7/07; publicado na web em 19/12/07

\begin{abstract}
The main objective of this paper was to evaluate the level of occurrence of the organochlorine compounds in samples of sediments, bivalves and two fish species collected in the Piracicaba River basin (São Paulo, Brazil). The isomers $\alpha$ and $\gamma$ of HCH and Heptachlor were most frequently detected in samples of sediments and specimens of bivalve and fish. Therefore, although the levels of these compounds found were not critically high, they are still found in the environment. This fact suggests that they are still being used, despite the fact that the use of these compounds was outlawed more than twenty years ago.
\end{abstract}

Keywords: organochlorines; biological monitor; Piracicaba River basin.

\section{INTRODUCTION}

Persistent organic pollutants, that are resistant to environmental degradation and persist in the environment, represent a global environmental problem and some of them, despite the fact that they have been outlawed, are still produced and used in several countries. Currently it is well established that past human activities have resulted in widespread environmental contamination with persistent chemicals especially in aquatic ecosystems ${ }^{1}$. These chemicals, due to their physical volatile chemical properties, can be transported from temperate and tropical climate zones through the air and re-deposited in remote regions such as Arctic and Antarctic regions ${ }^{2}$. The concern about certain chemicals, such as pesticides and heavy metals, has also increased from an ecotoxicological point of view since their residues pose a toxic threat to wildlife and to humans as well ${ }^{2}$.

The use of pesticides and consequences to the environment and human health has been evaluated much more in the developed industrialized countries than in the developing world. In industrialized areas of developing countries, agricultural defenses, insecticides and pesticides are widely used ${ }^{3}$. Among these, organochlorines are characterized by low biotic and non biotic degradability, low solubility in water, and low volatility at room temperature, endowing them with high persistence and promoting their widespread dissemination in the aquatic environment. When pesticides persist in water and food, they can pose hazards to farm workers, fish, wildlife, and consumers ${ }^{4}$. The countries in North, Central, and South America used, in 1993, 1.172.077 kg of DDT to spray house walls. While this may seem to be a large amount of insecticide, it actually represents less than $6 \%$ of the DDT used in

*e-mail:dmlsilva@gmail.com

"Endereço Atual: Departamento de Ciências Exatas e Tecnológicas, Universidade Estadual de Santa Cruz, Rodovia Ilhéus-Itabuna, km $1645662-000$ Ilhéus - BA, Brasil
United States alone, in $1968^{5}$. In Brazil, only in 1983, 100 millions $\mathrm{kg}$ of pesticides were consumed. Organochlorines importation as DDT, Endosulfan, Heptachlor, Lindane $(\gamma \mathrm{HCH})$, and Aldrin decreased from 1990 to 1992 , because some of them had been forbidden since the creation of the Law number 329/MA (Ministry of Agriculture of Brazil) of September/1985 5 .

The Piracicaba River basin, located in the State of São Paulo (southeast Brazil), is considered one of the most developed regions in the country. Approximately $30 \%$ of its area $\left(3,600 \mathrm{~km}^{2}\right)$ is devoted to sugar cane, which has been cultivated in this area for over a century. Because of its high population density in some areas of this basin and because it lacks of sewage treatment (only $16 \%$ of the total sewage load is treated) several zones of Piracicaba basin are facing acute pollution problems ${ }^{7}$. As a consequence, most of the major rivers in this basin have already altered their basic functioning due to the large load of urban sewage and industrial effluents dumped in these waters ${ }^{7,8}$. The main problem is the decrease in the water quality due to the extra input of organic matter provided by untreated sewage. In addition to these problems, elevated concentrations of heavy metals such as $\mathrm{Hg}, \mathrm{Cd}$, and $\mathrm{Pb}$ were found in samples of sediments, fish, and mussels ${ }^{9-11}$. However, no basin-wide evaluation on pesticides concentrations has ever been conducted. Due to the fact that organochlorines had officially been used for many years in the sugar-cane fields, the main objective of this paper was to evaluate the levels of organochlorine compounds ( $\alpha \mathrm{HCH}$ (Hexachlorocyclohexane), $\beta \mathrm{HCH}, \gamma \mathrm{HCH}$, Heptaclor, Aldrin, Endrin, Dieldrin, DDE (Dichlorodiphenildichloroehtylene), DDT (Dichlorodiphenyltrichloroethane), $\alpha$ Endosulfan, and $\beta$ Endosulfan) in samples of sediments, bivalves Anodontites trapesialis (Lamarck, 1819), and two fish species - Prochilodus scrofa (Steindachner, 1881) and Pimelodus maculatus (Lacepede, 1803) collected in the Piracicaba River basin (São Paulo, Brazil). The main hypothesis of this study is that organochlorines can still be found in the environment though their use was banned in 1985 . 


\section{EXPERIMENTAL}

\section{Sampling}

The Atibaia River sampling sites S1 and S2 are located upstream and downstream, respectively (Figure 1). Further downriver the Atibaia River forms the Salto Grande reservoir (S8). The S4 site is located in the upper part of the reservoir in a floodplain-like area, being a transition between the river and the reservoir itself. In contrast, the S5 site is located further down in the reservoir in a typical lentic environment. The sampling site S3 is located in the Jaguari River. This river and the Atibaia River merge to form the Piracicaba River, where sampling sites S6 and S7 are located.

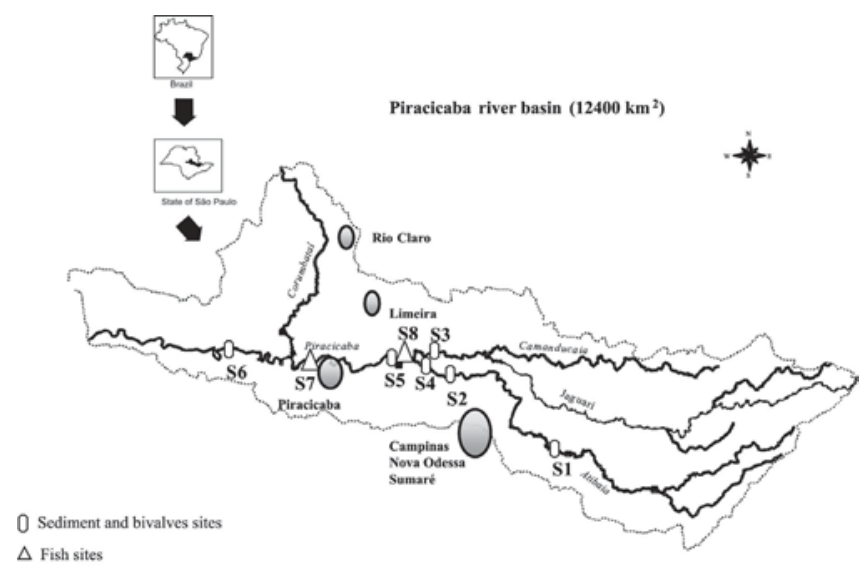

Figure 1. Study sites in Piracicaba River basin

Abiotic parameters, $\mathrm{pH}$ (Orion 250A meter), electrical conductivity (Science 2052 meter), and dissolved oxygen (oximeter YSI model 58) were measured monthly in the field in water samples collected in the sampling sites S1 to S6 (Figure 1).

The sampling of sediments and bivalves were conducted in the sampling sites S1 to S6 during the dry (April to September) and rainy seasons (January to March) of 1997. Fish samples were also taken in both periods of 1998 at sampling sites S7 and S8. In total twelve sediment samples were collected: six during the dry season and six during the rainy season, one in each sampling site. Three specimens of bivalves were collected during the dry and rainy seasons in sampling sites S1 to S6, totaling six specimens per sampling site per year in a total of thirty six specimens analyzed for pesticides. Finally, five specimens of $P$. scrofa were captured during the dry and rainy season at sampling site S7, totaling ten specimens captured in this sampling site. In sampling site S8, a small number of specimens were captured, two during the dry season and three during the rainy season. Therefore, fifteen specimens of $P$. scrofa were captured. Three specimens of $P$. maculates were captured during the dry and rainy season at sampling site S7, totaling six specimens at this sampling site. A total of seven specimens were captured at sampling site S8: four specimens were captured during the dry season and three during the rainy season. Therefore, thirteen specimens of $P$. maculates were captured at sampling S8.

Sediments were collected with an Eckman dredger at a depth of $5-10 \mathrm{~cm}$ in the same site where bivalves were collected. These samples were frozen, and in the laboratory they were defrosted at room temperature, dried in stoves and sieved.

Several authors have described the characteristics of the ideal sentinel species, that are biological monitors that can accumulate pollutants in their tissues and used to measured the levels of these contaminants, showing mussels as having the most impressive record as general monitors ${ }^{12,13}$. The "Mussel Watch" concept, that is, the use of sentinel organisms to monitor the concentration of selected pollutants in coastal environment and as an indicator of their bioavailability, has gained widespread acceptance and programs are employed on a national as well as international basis ${ }^{14}$. Mollusks are excellent biological monitors for detecting organochlorine pesticides for various reasons: they are sedentary, filter large quantities of water to obtain food and oxygen, have a key position in the food chain, live long enough to be exposed to the compounds been evaluated, and concentrate compounds by factors of $10^{2}-10^{5}$

The bivalve Anodontites trapesialis (Lamarck, 1819) was used in this study. This species belongs to the Mycetopodidade family widespread in South America, particularly in Brazil. They live in muddy, clay, and sandy muddy substrate at a depth of 10-19 cm. Mollusks are easily located and captured by probing the substrate with hands or feet ${ }^{15}$.

Approximately, 150 specimens of Anodontites trapesialis were collected by hand from the Pardo River (State of São Paulo, Brazil). In order to obtain a homogeneous stand, individuals measuring 10 $\mathrm{cm}$ in length and $90 \mathrm{~g}$ in weight were selected. The animals were transported to the laboratory and kept for 40 days in tanks filled with water from a natural spring so that they could be kept clean. This period was enough to allow the depuration of contaminants ${ }^{16}$. Four animals of this group were separated and used as a control group, and then the others were placed in rivers of the Piracicaba Basin.

In the sampling sites, animals were prepared with a nylon line attached to the umbonal region in one of the valves of the animal with epoxy cement, and then the other end of the nylon lines was bound to trees, and while the mollusks were placed in the river bottom $^{17}$. In each station, six animals were introduced and left for 32 days in the sampling sites, when they were recaptured and frozen. In laboratory, the soft parts were removed, weighed and homogenized in a $250 \mathrm{~mL}-$ Potter apparatus. Samples of $5 \mathrm{~g}$ were separated and freeze-dried, resulting in approximately $1 \mathrm{~g}$ of dry sample.

Fish are the most studied organisms in toxicological studies due to their ecological role (predator/prey) and because of their commercial role as human food. They are important in biomonitoring programs because they exploit different trophic levels and because they move freely in aquatic ecosystems exploring all regions in a watershed ${ }^{18}$.

Fifteen individuals of the bottom feeder Prochilodus scrofa and thirteen individuals of the carnivorous Pimelodus maculatus were caught by local fishermen. These samples were collected in river stretches along the city of Piracicaba (S7) and in the reservoir Salto Grande (S8), near the city of Americana (Figure 1). Fish were defrosted at room temperature and fillets of approximately 10-30 g were cut, homogenized in a blender and lyophilized to posterior analysis.

\section{Method}

The compounds analyzed were $\alpha \mathrm{HCH}, \beta \mathrm{HCH}, \gamma \mathrm{HCH}$, Heptaclor, Aldrin, Endrin, Dieldrin, DDE, DDT, $\alpha$ Endosulfan, and $\beta$ Endosulfan. Accelerated solvent extraction (ASE): extraction was carried out using a home-built ASE developed at the Chromatography Laboratory at the Chemistry Institute, University of São Paulo (Brazil) ${ }^{19}$. The extraction consists of a heating phase $(10 \mathrm{~min})$ and static (5 min) and dynamic cycles ( 2 cycles). Samples of 0.5 to $2 \mathrm{~g}$ were used in the extraction and the time for static extraction was 5 min and two cycles of $10 \mathrm{~min}$ dynamic after $10 \mathrm{~min}$ equilibration. 
Following static extraction, the valve was opened and a dynamic cycle of 3 to 5 min started. As a final step, the vessel was purged with gaseous nitrogen. The total amount of extracted solvent was $10 \mathrm{~mL}$. The organochlorine compounds were identified by comparing the retention time to the standard and real samples. The quantification was performed through external standard. All solvents (hexane, acetone, and ethyl acetate) used were analytical grade (Merck and Mallinckrodt).

\section{Chromatography analysis}

GC/ECD (Gas Chromatography/Electron Capture Detector) analyses were performed on a Hewlett Packard model HP 5890 series II, equipped with a split/splitless injector. The temperature of injector and detector were 250 and $300{ }^{\circ} \mathrm{C}$ respectively. A LM-5 capillary column, $25 \mathrm{~m}$ x $0.35 \mathrm{~mm} \times 0.35 \mu \mathrm{m}$, was used. The carrier gas was hydrogen and the make-up gas was nitrogen. The temperature program was as follows: initial temperature $140{ }^{\circ} \mathrm{C}$, followed by $4{ }^{\circ} \mathrm{C} \mathrm{min}^{-1}$ ascent to $230{ }^{\circ} \mathrm{C}$, followed by $12{ }^{\circ} \mathrm{C} \mathrm{min}{ }^{-1}$ ascent to $300{ }^{\circ} \mathrm{C}$ held for 5 min. All values were confirmed in GC/MS (Gas Chromatography/ Mass Spectrometry - Shimadzu MSD QP-5000).

\section{Organic carbon}

The elementar carbon was determined by the combustion of the samples, at high temperature $\left(1000{ }^{\circ} \mathrm{C}\right)$ in an elemental analyzer Carlo Erba (CHN-1110). The $\mathrm{CO}_{2}$ release was separated by the other byproducts through chromatography combustion and detected by termocondutance. The value found was compared with a standard through the interpolation of areas.

\section{Validation}

The standards used in the extracts were supplied by Aldrich. To validate the method, the samples of sediment, bivalves and fish were spiked at concentration levels of $1 \mu \mathrm{g} \mathrm{g}^{-1}$ of a pool of organochlorine.

The parameters used for validation were based on accuracy, precision, linearity, detection limits, and quantification limits ${ }^{20}$. The EPA (Environmental Protection Agency) ${ }^{20,21}$ and GARP (Grupo de Analistas de Resíduos de Pesticidas) guidelines ${ }^{21}$ established for pesticide analysis stipulates that coefficients of variation should be no higher than \pm 15 and $\pm 30 \%$, respectively. The coefficient of variation found for sediment samples ranged from 2 to $19 \%$ and from 1 to $16 \%$ for samples of bivalves, showing that most of our values were in the range of the acceptable limits (Table 1). In relation to accuracy, our values were also below the acceptable limits of $20 \%$ established by GARP (Table 1). For fish samples, the values of coefficient of variation and accuracy were higher than the values of sediment and bivalves samples. The main cause for this was the higher lipid content of fish in relation to other matrices, causing an increase in the adsorption of organochlorine compounds, increasing the values above acceptable limits (Table 1).

\section{RESULTS}

\section{Water and sediment characteristics of the sampling sites}

There was no statistical difference in $\mathrm{pH}$, and water temperature (Table 2). The dissolved oxygen concentrations vary from 7 to 9 $\mathrm{mg} \mathrm{L}^{-1}$ in sampling sites $\mathrm{S} 1, \mathrm{~S} 2$, and $\mathrm{S} 3$. There was a small decrease to around $6 \mathrm{mg} \mathrm{L}^{-1}$ at $\mathrm{S} 5$ and sharp decrease at $\mathrm{S} 4$ and S6, which are considered the most polluted sites in the Piracicaba River basin? The water conductivity values are generally smaller at sampling sites with higher dissolved oxygen concentration (Table 2). The exception to this pattern is S6, where the lowest dissolved oxygen concentration was observed, but not the highest water conductivity value (Table 2). The sediments of the Piracicaba River basin were primarily composed of sand $(52.3 \%)$, followed by silt $(29.0 \%)$ and clay $(18.7 \%)$. The carbon concentration in sediment samples was higher at site S4 (2.4\%), which coincides with the major values of organochlorines found in sediment samples (Table 2).

\section{Organochlorine concentrations in sediment samples}

The $\alpha \mathrm{HCH}$ was found in every sampling site from S1 to S6. The concentrations ranged from below the detection limit to 0.044 $\mu \mathrm{g} \mathrm{g}^{-1}$ (Table 3). Among the sampling sites, the highest concentrations of organochlorine compounds and a higher number of compounds in sediment samples $(\alpha \mathrm{HCH}$, Aldrin, Endin, and Endossulfan) were observed in sites S2, S4, and S5 (Table 3). Sampling site S2 is located in reach of the Atibaia River free of the heavy untreated sewage load discarded by large cities such as Campinas. Sampling sites S4 and S5 are both located in the same reservoir (Salto Grande) which is formed by the Atibaia River after this river receives a heavy load of untreated domestic sewage from Campinas and other cities ${ }^{6}$ (Figure 1).

Table 1. Results of validation to different matrices (sediment, bivalves, and fish)

\begin{tabular}{|c|c|c|c|c|c|c|c|c|c|c|c|c|}
\hline & $\begin{array}{c}\mathrm{CV} \\
\%\end{array}$ & $\begin{array}{c}\text { REC } \\
\%\end{array}$ & $\begin{array}{c}\text { LOD } \\
\left(\mu \mathrm{g} \mathrm{g}^{-1}\right)\end{array}$ & $\begin{array}{c}\text { LOQ } \\
\left(\mu \mathrm{g} \mathrm{g}^{-1}\right)\end{array}$ & $\begin{array}{c}\text { CV } \\
\%\end{array}$ & $\begin{array}{c}\text { REC } \\
\%\end{array}$ & $\begin{array}{l}\text { LOD } \\
\left(\mu \mathrm{g} \mathrm{g}^{-1}\right)\end{array}$ & $\begin{array}{c}\text { LOQ } \\
\left(\mu \mathrm{g} \mathrm{g}^{-1}\right)\end{array}$ & $\begin{array}{l}\mathrm{CV} \\
\%\end{array}$ & $\begin{array}{c}\text { REC } \\
\%\end{array}$ & $\begin{array}{c}\text { LOD } \\
\left(\mu \mathrm{g} \mathrm{g}^{-1}\right)\end{array}$ & $\begin{array}{c}\text { LOQ } \\
\left(\mu \mathrm{g} \mathrm{g}^{-1}\right)\end{array}$ \\
\hline & \multicolumn{4}{|c|}{ Sediment } & \multicolumn{4}{|c|}{ Bivalve } & \multicolumn{4}{|c|}{ Fish } \\
\hline$\alpha \mathrm{HCH}$ & 16.44 & 94.91 & 0.006 & 0.017 & 0.81 & 91.75 & 0.014 & 0.043 & 8.58 & 93.42 & 0.020 & 0.060 \\
\hline$\gamma \mathrm{HCH}$ & 2.44 & 97.93 & 0.003 & 0.008 & 1.39 & 82.19 & 0.005 & 0.015 & 9.94 & 109.5 & 0.003 & 0.009 \\
\hline$\beta \mathrm{HCH}$ & 17.10 & 104.9 & 0.020 & 0.060 & 11.43 & 91.63 & 0.050 & 0.150 & 4.24 & 96.07 & 0.060 & 0.180 \\
\hline Heptacloro & 13.51 & 79.81 & 0.001 & 0.002 & 2.85 & 95.60 & 0.002 & 0.006 & 10.15 & 114.7 & 0.005 & 0.015 \\
\hline Aldrin & 18.63 & 79.00 & 0.003 & 0.008 & 3.55 & 78.00 & 0.002 & 0.005 & 10.12 & 95.31 & 0.001 & 0.004 \\
\hline$\alpha$ Endosulfan & 12.84 & 77.30 & 0.002 & 0.003 & 16.03 & 85.13 & 0.002 & 0.006 & 7.47 & 90.97 & 0.002 & 0.006 \\
\hline Dieldrin & 11.64 & 79.28 & 0.001 & 0.004 & 13.13 & 79.18 & 0.002 & 0.007 & 10.97 & 80.94 & 0.001 & 0.003 \\
\hline DDE & 11.19 & 80.69 & 0.005 & 0.015 & - & - & - & - & 13.35 & 73.78 & 0.004 & 0.008 \\
\hline Endrin & 2.78 & 80.40 & 0.003 & 0.008 & 3.80 & 83.32 & 0.003 & 0.009 & 9.69 & 92.87 & 0.007 & 0.020 \\
\hline$\beta$ Endossulfan & 5.60 & 82.18 & 0.005 & 0.015 & 7.74 & 78.65 & 0.007 & 0.021 & 9.90 & 84.68 & 0.010 & 0.030 \\
\hline DDT & 2.04 & 91.50 & 0.007 & 0.020 & 6.24 & 94.25 & 0.012 & 0.036 & 19.61 & 103.5 & 0.050 & 0.150 \\
\hline
\end{tabular}

(CV: coefficient of variation; REC: recovery; LOD: limit of detection; LOQ: limit of quantification) 
Table 2. Abiotic factors and granulometric analyses in water and sediments respectively in the study site

\begin{tabular}{|c|c|c|c|c|c|c|}
\hline & Site 1 & Site 2 & Site 3 & Site 4 & Site 5 & Site 6 \\
\hline $\mathrm{pH}$ & $6.6 \pm 0.19$ & $6.9 \pm 0.13$ & $7.2 \pm 0.32$ & $6.9 \pm 0.23$ & $6.9 \pm 0.29$ & $6.7 \pm 0.02$ \\
\hline $\begin{array}{l}\text { Temperature } \\
\left({ }^{\circ} \mathrm{C}\right)\end{array}$ & $19.8 \pm 3.96$ & $23.9 \pm 2.68$ & $21.5 \pm 4.59$ & $23.6 \pm 4.87$ & $23.2 \pm 3.82$ & $26.8 \pm 0.35$ \\
\hline $\begin{array}{l}\text { Dissolved } \\
\text { Oxigen }(\mu \mathrm{M})\end{array}$ & $250.5 \pm 25.8$ & $223.7 \pm 9.28$ & $299.2 \pm 29.8$ & $142.3 \pm 44.4$ & $192.8 \pm 55.6$ & $76.5 \pm 103.0$ \\
\hline $\begin{array}{l}\text { Condutivity } \\
\left(\mu \mathrm{S} \mathrm{cm}^{-1}\right)\end{array}$ & $57.0 \pm 14.2$ & $178.2 \pm 42.2$ & $142.0 \pm 98.9$ & $291.0 \pm 200.8$ & $150.0 \pm 3.76$ & $177.4 \pm 89.8$ \\
\hline Sand $(\%)$ & 44.5 & 73.0 & 42.0 & 75.0 & 39.5 & 40.0 \\
\hline Clay $(\%)$ & 31.0 & 16.0 & 35.0 & 17.5 & 37.0 & 37.0 \\
\hline Silt (\%) & 24.5 & 11.0 & 23.0 & 7.50 & 23.5 & 23.0 \\
\hline $\begin{array}{l}\text { Organic } \\
\text { Matter (\%) }\end{array}$ & 1.4 & 0.4 & 1.6 & 2.4 & 1.3 & 1.3 \\
\hline
\end{tabular}

Table 3. Average concentration $\left(\mu \mathrm{g} \mathrm{g}{ }^{-1}\right)$ of organochlorine compounds detected in sediment samples in dry and rainy season

\begin{tabular}{|c|c|c|c|c|c|c|c|c|c|c|c|c|}
\hline & \multicolumn{2}{|c|}{ Site 1} & \multicolumn{2}{|c|}{ Site 2} & \multicolumn{2}{|c|}{ Site 3} & \multicolumn{2}{|c|}{ Site 4} & \multicolumn{2}{|c|}{ Site 5} & \multicolumn{2}{|c|}{ Site 6} \\
\hline & rainy & dry & rainy & dry & rainy & dry & rainy & dry & rainy & dry & rainy & dry \\
\hline$\alpha \mathrm{HCH}$ & n.d & 0.030 & n.d & $<0.017$ & n.d & $<0.017$ & n.d & 0.044 & n.d & 0.040 & n.d & 0.019 \\
\hline$\gamma \mathrm{HCH}$ & n.d & n.d. & n.d. & n.d. & n.d. & n.d. & n.d & n.d. & n.d. & $<0.007$ & n.d & n.d. \\
\hline$\beta \mathrm{HCH}$ & n.d & n.d. & 0.020 & n.d. & n.d. & n.d. & n.d & $<0.020$ & n.d. & n.d. & n.d & n.d. \\
\hline Aldrin* & $<0.003$ & n.d. & 0.003 & 0.030 & $<0.003$ & n.d. & n.d & n.d. & n.d. & 0.045 & n.d & n.d. \\
\hline Heptachlor & n.d. & n.d. & n.d & $<0.002$ & n.d. & n.d. & 0.007 & $<0.002$ & n.d. & n.d. & n.d & n.d. \\
\hline Dieldrin* & $<0.001$ & n.d. & $<0.001$ & 0.004 & n.d. & n.d. & 0.004 & n.d. & n.d & $<0.004$ & $<0.001$ & n.d. \\
\hline$\beta$ Endosulfan & n.d & n.d. & n.d & $<0.015$ & n.d & n.d. & $<0.015$ & n.d. & n.d. & 0.015 & n.d. & $<0.015$ \\
\hline Endrin* & n.d & n.d. & 0.003 & n.d. & n.d. & $<0.003$ & 0.008 & n.d. & n.d. & 0.012 & $<0.007$ & n.d. \\
\hline DDE & $<0.015$ & $<0.005$ & $<0.005$ & $<0.005$ & n.d & n.d. & $<0.005$ & $<0.005$ & n.d. & n.d. & $<0.005$ & n.d. \\
\hline DDT & n.d & 0.020 & n.d & $<0.020$ & n.d & $<0.020$ & n.d & $<0.020$ & n.d. & n.d & $<0.020$ & $<0.020$ \\
\hline
\end{tabular}

n.d.: not detected; *values not confirmed by GC-MS

Table 4. Concentration ( $\mu \mathrm{g} \mathrm{g}^{-1}$ of wet weight) of organochlorine detected in bivalve samples in dry and rainy season (Average \pm Standard deviation)

\begin{tabular}{|c|c|c|c|c|c|c|c|c|c|c|c|c|}
\hline \multirow[b]{2}{*}{$(n=3)$} & \multicolumn{2}{|c|}{ Site 1} & \multicolumn{2}{|c|}{ Site 2} & \multicolumn{2}{|c|}{ Site 3} & \multicolumn{2}{|c|}{ Site 4} & \multicolumn{2}{|c|}{ Site 5} & \multicolumn{2}{|c|}{ Site 6} \\
\hline & rainy & dry & rainy & dry & rainy & dry & rainy & dry & rainy & dry & rainy & dry \\
\hline$\alpha \mathrm{HCH} *$ & $\begin{array}{c}0.009 \pm \\
0.003\end{array}$ & $\begin{array}{c}0.014 \pm \\
0.004\end{array}$ & n.d & $\begin{array}{c}0.007 \pm \\
0.012\end{array}$ & n.d & n.d & $\begin{array}{c}0.061 \pm \\
0.063\end{array}$ & $\begin{array}{c}0.036 \pm \\
0.062\end{array}$ & n.d & n.d & n.d & n.d \\
\hline$\gamma \mathrm{HCH}$ & $\begin{array}{c}0.112 \pm \\
0.074\end{array}$ & $\begin{array}{c}0.022 \pm \\
0.007\end{array}$ & $\begin{array}{c}0.246 \pm \\
0.069\end{array}$ & $\begin{array}{c}0.152 \pm \\
0.103\end{array}$ & $\begin{array}{c}0.244 \pm \\
0.084\end{array}$ & $\begin{array}{c}0.193 \pm \\
0.005\end{array}$ & $\begin{array}{l}0.136 \\
0.018\end{array}$ & $\begin{array}{c} \pm 0.174 \pm \\
0.021\end{array}$ & $\begin{array}{l}0.243 \\
0.149\end{array}$ & $\begin{array}{c} \pm 0.167 \pm \\
0.025\end{array}$ & $\begin{array}{l}0.226 \\
0.029\end{array}$ & $\begin{array}{c} \pm 0.243 \pm \\
0.071\end{array}$ \\
\hline$\beta \mathrm{HCH} *$ & n.d & n.d & n.d & n.d. & n.d. & n.d. & n.d & n.d & n.d. & n.d. & n.d & n.d. \\
\hline Heptachlor & $\begin{array}{c}0.004 \pm \\
0.003\end{array}$ & $\begin{array}{c}0.005 \pm \\
0.003\end{array}$ & $\begin{array}{c}0.013 \pm \\
0.004\end{array}$ & $\begin{array}{c}0.011 \pm \\
0.006\end{array}$ & $\begin{array}{l}0.012 \\
0.004\end{array}$ & $\begin{array}{c} \pm 0.091 \pm \\
0.089\end{array}$ & 0.007 & $\begin{array}{c}0.010 \pm \\
0.001\end{array}$ & $\begin{array}{c}0.011 \pm \\
0.008\end{array}$ & $\begin{array}{c}0.011 \pm \\
0.003\end{array}$ & $\begin{array}{c}0.012 \pm \\
0.001\end{array}$ & $\begin{array}{c}0.020 \pm \\
0.015\end{array}$ \\
\hline$\alpha$ Endosulfan* & n.d & n.d. & n.d. & n.d. & $\begin{array}{c}0.002 \pm \\
0.002\end{array}$ & $\begin{array}{c}0.005 \pm \\
0.009\end{array}$ & n.d. & n.d. & $\begin{array}{c}0.024 \pm \\
0.009\end{array}$ & $\begin{array}{c}0.009 \pm \\
0.010\end{array}$ & n.d. & n.d. \\
\hline Dieldrin & n.d. & n.d. & n.d. & n.d. & n.d. & n.d. & n.d. & n.d. & n.d. & n.d. & n.d. & n.d. \\
\hline$\beta$ Endossulfan & n.d. & n.d. & n.d. & n.d. & n.d. & n.d. & n.d. & n.d. & n.d. & n.d. & n.d. & n.d. \\
\hline Endrin* & n.d. & n.d. & n.d. & n.d. & n.d. & $\begin{array}{c}0.004 \pm \\
0.007\end{array}$ & n.d. & n.d. & n.d. & n.d. & n.d. & n.d. \\
\hline DDE & n.d. & n.d. & n.d. & n.d. & n.d. & n.d. & n.d. & n.d. & n.d. & n.d. & n.d. & n.d. \\
\hline DDT & n.d. & n.d. & n.d. & n.d. & n.d. & n.d. & n.d. & n.d. & n.d. & n.d. & n.d. & n.d. \\
\hline
\end{tabular}

*values not confirmed by GC-MS; n.d.: not detected; $\mathrm{n}=$ number of samples

\section{Organochlorine concentration in bivalve samples}

No organochlorine compounds were found in the control group of bivalve samples after approximately 40 days, which was the period that the bivalve remained in tanks with spring clean water before they were placed in sites of the Piracicaba River basin.

The $\gamma \mathrm{HCH}$ and Heptachlor compounds were found in bivalve samples of every sampling site (Table 4). However, although these two compounds were always present, their concentrations did not exceed the limit established for protection of aquatic life of 2.0 and $0.52 \mu \mathrm{g} \mathrm{L}^{-1}$, respectively ${ }^{22}$. The other compounds were below the detection limits or were not confirmed by GC-MS. 
Table 5. Concentration $\left(\mu \mathrm{g} \mathrm{g}^{-1}\right.$ of wet weight) of organochlorine compounds detected in fish samples in rainy and dry season (Average \pm Standard deviation)

\begin{tabular}{|c|c|c|c|c|c|c|c|c|}
\hline & \multicolumn{2}{|c|}{ Prochilodus scrofa (S7) } & \multicolumn{2}{|c|}{ Prochilodus scrofa (S8) } & \multicolumn{2}{|c|}{ Pimelodus maculatus(S7) } & \multicolumn{2}{|c|}{ Pimelodus maculatus(S8) } \\
\hline & dry $(n=5)$ & rainy $(n=5)$ & dry $(n=2)$ & rainy $(n=3)$ & dry $(n=3)$ & rainy $(\mathrm{n}=3)$ & dry $(n=4)$ & rainy $(n=3)$ \\
\hline$\alpha \mathrm{HCH}$ & $0.147 \pm 0.210$ & $0.303 \pm 0.254$ & $0.051 \pm 0.055$ & $0.414 \pm 0.192$ & $1.24 \pm 0.458$ & $0.194 \pm 0.376$ & n.d. & n.d. \\
\hline$\gamma \mathrm{HCH}$ & $0.237 \pm 0.326$ & $0.144 \pm 0.129$ & $0.153 \pm 0.264$ & $0.108 \pm 0.116$ & $0.125 \pm 0.095$ & $0.044 \pm 0.042$ & $0.027 \pm 0.047$ & n.d. \\
\hline$\beta \mathrm{HCH}$ & n.d. & n.d. & n.d. & n.d. & n.d. & $0.165 \pm 0.368$ & n.d. & n.d. \\
\hline Aldrin * & $0.078 \pm 0.089$ & $0.067 \pm 0.091$ & $0.108 \pm 0.095$ & $0.306 \pm 0.239$ & n.d. & n.d. & n.d. & n.d. \\
\hline Heptachlor & $0.022 \pm 0.019$ & $0.038 \pm 0.085$ & $0.040 \pm 0.045$ & n.d. & n.d. & $0.061 \pm 0.095$ & $0.016 \pm 0.027$ & n.d. \\
\hline$\alpha$ Endosulfan & n.d. & n.d. & n.d. & n.d. & n.d. & $0.027 \pm 0.047$ & n.d. & n.d. \\
\hline Dieldrin* & n.d. & n.d. & n.d. & n.d. & n.d. & n.d. & $0.398 \pm 0.293$ & n.d. \\
\hline$\beta$ Endosulfan & n.d. & n.d. & n.d. & n.d. & n.d. & n.d. & n.d. & n.d. \\
\hline Endrin * & 0.054 & n.d. & n.d. & n.d. & n.d. & n.d. & 0.124 & n.d. \\
\hline $\mathrm{DDE} *$ & n.d. & n.d. & n.d. & $0.144 \pm 0.102$ & n.d. & n.d. & n.d. & n.d. \\
\hline DDT $*$ & n.d. & $0.206 \pm 0.418$ & 0.151 & n.d. & n.d. & n.d. & n.d. & n.d. \\
\hline
\end{tabular}

* values not confirmed by GC-MS; n.d.: not detected; $\mathrm{n}=$ number of samples

Table 6. Concentration of organochlorine compounds in all samples (average and maximum - minimum values in $\mu \mathrm{g} \mathrm{g}^{-1}$ of wet weight)

\begin{tabular}{lccccccccccc}
\hline & $\alpha \mathrm{HCH}$ & $\beta \mathrm{HCH}$ & $\gamma \mathrm{HCH}$ & Aldrin & Heptaclor & $\alpha$ Endossulfan & $\beta$ Endossulfan & Dieldrin & Endrin & DDE & DDT \\
\hline Sediment & 0.014 & 0.001 & n.d. & $0.006^{*}$ & 0 & $0.010^{*}$ & n.d. & $0.0006^{*}$ & $0.001^{*}$ & n.d. & 0.001 \\
& n.d. & n.d. & $-<0.017$ & n.d. & n.d. & n.d. & $-<0.015$ & n.d. & n.d. & -0.005 & n.d. \\
& -0.044 & $-<0.020$ & & -0.030 & -0.007 & -0.050 & & -0.004 & -0.012 & -0.020 \\
Anodontites & $0.025^{*}$ & - & 0.180 & - & 0.025 & $0.010^{*}$ & $0.001^{*}$ & - & $<0.004^{*}$ & - & - \\
trapesialis & n.d. & & 0.022 & & 0.005 & n.d. & n.d. & & n.d. & \\
(Bivalve) & -0.061 & & -0.246 & & -0.182 & -0.024 & -0.012 & & -0.004 & \\
Prochilodus & 0.203 & - & 0.184 & 0.134 & 0.035 & 0.011 & - & 0.008 & - & 0.032 & 0.078 \\
scrofa & 0.051 & & 0.108 & 0.067 & n.d. & n.d. & & n.d. & n.d. & n.d. \\
(Fish) & -0.414 & & -0.326 & -0.108 & -0.085 & -0.058 & & -0.043 & -0.144 & -0.206 \\
Pimelodus & 0.083 & 0.067 & 0.047 & $0.032^{*}$ & 0.025 & 0.009 & - & $0.036^{*}$ & - & $0.033^{*}$ & $0.350^{*}$ \\
maculatus & n.d. & n.d. & n.d. & n.d. & n.d. & n.d. & & n.d. & n.d. & n.d. \\
(Fish) & -1.240 & -0.368 & -0.125 & -0.063 & -0.095 & -0.047 & & -0.152 & -0.087 & -1.443 \\
\hline
\end{tabular}

*values not confirmed by GC-MS; n.d.: not detected

\section{Organochlorine in fish samples}

It is clear that the compounds $\alpha$ and $\gamma \mathrm{HCH}$ were frequently found in fish samples (Table 5). The highest average concentration of organochlorine was found during the dry season in specimens of Pimelodus maculatus captured at sampling site S7, near the city of Piracicaba. Heptachlor was also frequently detected, and confirmed by GC-MS analysis.

\section{DISCUSSION}

Despite the fact that the organochlorine compounds have been banned for more than two decades, several of these compounds, mainly the three isomers of $\mathrm{HCH}$ and Heptachlor, were still found in 1997 in the Piracicaba River basin. Below we discuss the presence of such organochlorine compounds in environmental samples and compared them with other regions of the world.

$\mathrm{HCH}$ arrived in Brazil in 1948, being the only organochlorine with insecticide properties ${ }^{23}$. It has been recognized that $\mathrm{HCH}$ is a highly volatile substance (atmospheric half life of 2.3 to 7.3 years ${ }^{24}$ ) and have been detected in soils, plants, animals and in water. Therefore, its appearance in environmental samples indicates recent use of these compounds $\mathrm{s}^{25-28}$.

Mainly the isomer $\alpha \mathrm{HCH}$ was found in higher concentration in bivalves and fish compared to sediment samples (Table 6). Concern over bioaccumulation starts with the publication of "Silent Spring" in 1962 where Rachel Carlson reported the contamination of bird eggs by DDT, showing the bioaccumulative capacity of this organic pesticide. Further, several studies have shown that exposure to organic pollutants is usually the result of transport up the food chain, concentrating in organisms with high lipid contents, such as fish, having high amounts of these contaminants ${ }^{3,29}$. The biomagnification begins with the adsorption of pesticides into suspended solids particles, which contributes to the removal of pesticides from the water column, and then can reach the highest levels in the trophic web, ranging from algae and bivalves to fish, birds and mammals ${ }^{2,3,30-34}$.

The HCH compounds were also detected in other regions of Brazil and other parts of the world. For instance, in Brazil $\gamma \mathrm{HCH}$ was detected in bivalves collected in bodies of water of the State of São Paulo, such as the Pardo River ${ }^{16}$ and in the Barra Bonita reservoir ${ }^{33}$. In Paranoá Lake (Federal District of Brasília), high concentrations of $\mathrm{HCH}$ were found in sediment and fish samples compared to water samples ${ }^{31}$. In other parts of the world, $\mathrm{HCH}$ was the most abundant pesticide found in the Waikato River and the most prevalent pesticide detected in a variety of human tissues collected from the New Zealand population ${ }^{1}$. High concentrations of $\alpha$ and $\beta \mathrm{HCH}$ were also found in surface sediments in rivers in China $^{35}$, and in specimens of Cyprinus carpo collected from the Meric River in Turkey ${ }^{36}$. Studies in the Turia River in Spain showed 
that bottom dwelling fish species could accumulate $\mathrm{HCH}^{37}$.

Even though we found Heptachlor in concentrations below the limit concentration of $0.100 \mu \mathrm{g} \mathrm{g}^{-1}$, its presence in sediment, bivalve, and fish specimens is intriguing since its use has been banned (Table 6). Studies developed in streams of State of São Paulo (Brazil) showed that the higher concentrations of organochlorine compounds in sediment samples were found in streams located near sugar cane crops $^{38}$. As several of our sampling sites are surrounded by sugar cane fields, it is reasonable to hypothesize that, although outlawed, Heptachlor is still probably being used in sugar cane crops.

\section{CONCLUSION}

Although the levels of organochlorine compounds found in the Piracicaba River basin are not critically high, our hypothesis was confirmed; we found organochlorine contamination in several samples. The fact that they are still found in the environment, suggests that they are still being used, despite the fact that the use of these compounds were banned more than twenty years ago in the country. The sources of these compounds could be either agricultural activities or non point sources, such as atmospheric inputs. Therefore, it is clear that broader monitoring of organochlorine compounds should be carried out in the Piracicaba River basin. In addition, an in depth investigation on the use of such prohibited compounds should be conducted. Finally, actions to mitigate potential consequences of organochlorine compound accumulation in the environment are also urgently needed.

\section{ACKNOWLEDGMENT}

We acknowledge Fapesp, CNPq and ESSO Brasileira de Petróleo for financial support for this work. It is also necessary to thank personnel at Laboratory of Chromatography (USP-São Carlos), Laboratory of Invertebrate Zoology (FFCLRP-USP) and Laboratory of Isotopic Ecology (CENA-USP) for assistance in field and in laboratory analyses.

\section{REFERENCES}

1. Hickey, C. W.; Buckland, J.; Hanna, D. J.; Ropper, D. S.; Stuben, K.; Bull. Environ. Contam. Toxicol. 1997, 59, 106.

2. Strandberg, B.; Strandberg, L.; Bavel, B.; Bergvist, P. A.; Broman, D. Falandysz, J.; Naf, C.; Papakosta, O.; Rolff, C.; Rappe, C.; Sci. Total Environ. 1998, 215, 69.

3. Berg, H.; Kiibus, M.; Kautsky, N.; Ambio 1992, 21, 444.

4. Unnerveh, L. J.; Pingali, P. L.; Zilberman, D.; Food Policy 1997, 22, 105.

5. Roberts, D. R.; Laughlin, L. L.; Hahein, P.; Legters, L. J.; Emerg. Infect Dis. 1997, 3, 1.

6. Almeida, F. V.; Tese de Doutorado, Universidade Estadual de Campinas,
Brasil, 2003.

7. Martinelli, L.A.; Krusche, A.V.; Victoria, R. L.; Camargo, P. B.; Bernardes, M.; Ferraz, E. S.; Moraes, J. M.; Ballester, M. V.; Water, Air, Soil Pollut. 1999, 110, 67.

8. Krusche, A. V.; de Carvalho, F. P.; de Moraes, J. M.; de Camargo, P. B.; Ballester, M. V. R.; Hornink, S.; Martinelli, L. A.; Victoria, R. L.; J. Am. Water Resour. Assoc. 1997, 33, 1117.

9. Falótico, M. H. B.; Tese de Doutorado, Universidade de São Paulo, Brasil, 2001.

10. Tomazelli, A. C.; Martinelli, L. A.; Avelar, W. E. P.; Camargo, P. B.; Fostier, A. H.; Ferraz, E.S. B.; Krug, F. J.; Santos Jr, D.; Arch. Biol. Tech. 2003, 46, 673.

11. Tomazelli, A. C.; Martinelli, L. A.; Krug, F. J.; Santos, D.; Rufini, I.; Camargo, P. B.; Horvat, M.; J. Environ. Qual. 2007, 36, 478.

12. Viarengo, A.; Canesi, L.; Aquaculture 1991, 94, 225.

13. Beeby, A.; Environ Pollut. 2001, 112, 285.

14. Tavares, T. M.; Rocha, V. C.; Porte, C.; Barcelo, D.; Albaiges, J.; Mar. Pollut. Bull. 1988, 19, 575.

15. Avelar, W. E. P.; Nather, F. C.; Figueiredo, M. G.; Casanova, I. C.; Lopes, J. L. C.; An. Acad. Brás. Cienc. 1991, 63, 337.

16. Lopes, J. L. C.; Casanova, I. C.; Figueiredo, M. G.; Nather, F. C.; Avelar, W. E. P.; Arch. Environ. Contan. Toxicol. 1992, 23, 352.

17. Bedford, J. W.; Roelofs, E. W.; Zabik, M. J.; Limnol. Oceanogr. 1968, 13,118.

18. Fernandez, M. A.; Alonso, C.; Gonzáles, M. J.; Hernandez, L. M.; Chemosphere 1999, 38, 33.

19. Pinto, J. S. S.; Tese de Doutorado, Universidade de São Paulo, Brasil, 1998.

20. Bressoli, F.; Bromte-Petit, M.; Audran, M.; J. Chromatogr., A 1996, 686, 3.

21. Gou, Y.; Tragas, C.; Lord, H.; Pawlinski, J.; J. Microcolumn Sep. 2000, $12,125$.

22. Environmantel Protection Agency; Ambient Water Quality Criteria, 1980.

23. Lara, W. H.; de Batista, G. C.; Quim Nova 1992, 15, 161.

24. Murayama, H.; Shimizu, K.; Tsukada, N.; Shimada, A.; Kodama, T.; Kitayama, Y.; Chem. Commun. 2003, 2678.

25. Fu, J.; Mai, B.; Sheng, G.; Zhang, X.; Peng, P. A.; Xiao, X.; Ran, R.; Cheng, F.; Peng, X.; Wang, Z.; Tang, W.; Chemosphere 2003, 52, 1411.

26. Raldua, D.; Fernando, P.; Duran, C.; Pedrocchi, C.; Chemosphere 1997, $35,2245$.

27. Svobodova, Z.; Zlabek, V.; Randak, T.; Machova, J.; Kolarova, J.; Hajslova, J.; Suchan, P.. Acta Vet. 2003, 72, 295.

28. do Nascimento, N. R.; Nicola, S. M. C.; Rezende, M. O. O.; Oliveira, T. A.; Oberg, G.; Geoderma 2004, 121, 221.

29. Bordajni, L. R.; Gómez, G.; Fernandez, M. A.; Abad, E.; Rivera, J.; Gonzáles, M. J.; Chemosphere 2003, 53, 163.

30. Wilson, R.; Allen-Gil, S.; Griffin, D.; Landers, D.; Sci. Total Environ. 1995 160/161, 511

31. Caldas, E. D.; Coelho, R.; Souza, L. C. K. R.; Silva, S. C.; Bull. Environ. Contam. Toxicol. 1999, 62, 199.

32. Borga, K.; Gabrielsen, G. W.; Skaare, J. U.; Chemosphere 2003, 53, 685.

33. Calheiros, D. F.; Disertação de Mestrado, Universidade de São Paulo, Brasil, 1993.

34. da Silva, A. M. F.; Lemes, V. R. R.; Barretto, H. H. C.; Oliveira, E. S.; de Alleluia, P.; FJR 2003, 70, 1151.

35. Ding, H.; Ling, X. G.; Liu, H.; Wang, J.; Shen, W. R.; Sun, Y. C.; Shao, X. L.; J. Environ. Sci. - China 2005, 17, 731.

36. Erkman, B.; Kolankaya, D.; Int. J. Environ. Anal. Chem. 2006, 86, 161.

37. McCarthy, L. H.; Stephens, G. R.; Whittle, D. M.; Peddle, J.; Harbicht, S.; LaFontane, C.; Gregor, D. J.; Sci. Total Environ. 1997, 197, 55.

38. Corbi , J. J.; Strixino, S. T.; do Santos, A.; Del Grande, M.; Quim. Nova 2006, 29, 61. 